\title{
GLOBAL SUPPLY CHAINS AND THE SUSTAINABLE DEVELOPMENT
}

\author{
Bistra Nikolova Boeva, ${ }^{1}$ Stela Georgieva Zhivkova, ${ }^{2}$ Ivan Stoyanov Stoychev ${ }^{3}$
}

\begin{abstract}
Sustainable development issues are considerably popular subjects within the international research community. On the other hand the importance of the issues related to global supply chains has also increased significantly. This paper will also mention a change in one of the main economic paradigms: from international exchange between countries and individual companies there is a transition to exchange between the participants along the global supply chains. The interest in global supply chains and their management is provoked by the fact that they are a major source of competitive advantage on global markets. Nowadays, global supply chains are an integral part of the activities of a number of companies operating abroad. Every business operation finds its place in one or more supply chains. Within the contemporary context of scarce resources and the widely spread sustainable development idea, the companies compete on a global economic scale where the main business unit is the world as a whole, not an individual country or region. All these trends and global developments provoked our scientific interest and with the project "Corporate governance and the global supply chains" we tried to find out how the global supply chains are actually influenced by the issues of sustainable development. Within the course of the project we have reviewed and analyzed quite a lot of scientific literature, we studied the publicly available information of the big international corporations related to their social corporate responsibility and sustainable development issues. In addition, we have made empirical research among local suppliers of big international companies as well as a number of international NGOs dealing with sustainable development and social policy issues. Some of the findings from our project are presented in the current paper.
\end{abstract}

JEL Classification Numbers: F23, M14, Q01; DOI: http://dx.doi.org/10.12955/cbup.v5.975

Keywords: corporate governance, sustainable development, global supply chains

\section{Introduction}

The interest on global supply chains (GSC) and their management has been provoked by the fact that they are a major source of competitive advantage on the global market. Nowadays, global supply chains are an integral part of the business of a number of companies operating abroad. Every business sphere finds its place in one or more supply chains. The companies compete in the global economy where the business unit of analysis is the world as a whole, not the individual country or region. Kotler (1997) states that "when companies go global, they realize that regardless of their size they lack the necessary resources and tools to achieve success. Looking at the entire supply chain as a chain that creates value they realize the need for partnership with other organizations". That is why today there is an increasing interest both from academia and from the business community, to the specificities of the global supply chains' management as a new way of doing business, in order to increase the competitiveness of companies involved in the international business. On the other hand, sustainable development is another aspect of the global economic environment. The sustainable development concept enters into every detail of the production process and the way the companies are doing business worldwide. Therefore, it also inevitably influences the global supply chains. All these trends and global developments provoked our scientific interest and with the project "Corporate governance and the global supply chains" we tried to find out how the global supply chains are actually influenced by sustainable development issues on one hand and on other hand how they reflect on the corporate governance. The methods used in the project are the review and analysis of academic literature and different projects papers, study of the publicly available information on the big international corporations' websites as well as empirical research among local suppliers of big international companies as well as a number of international NGOs dealing with sustainable development and social policy issues. Some of the findings related to the global supply chains are presented below.

\section{Sustainable development and the supply chains}

Sustainable development is the most discussed issue nowadays. There is a variety of definitions for sustainable development and its characteristics.

Sustainable development is not a modern concept but in our century it gains a lot of popularity. It is seen as the development that ensures the well-being of the present generation without threatening the

\footnotetext{
${ }^{1}$ University for National and World Economy, Sofia, Bulgaria; bboeva@gmail.com

${ }^{2}$ University for National and World Economy, Sofia, Bulgaria; st_zhivkova@yahoo.com

${ }^{3}$ University for National and World Economy, Sofia, Bulgaria; i_stoytchev@yahoo.com
} 
survival and the normal living of future generations (Brundtland, 1987). Sustainability stands on the most important bases of the life of every society - economic development, social equity and environmental protection. These characteristic of sustainable development will be taken as a base for determining the main changes in the supply change management.

On the other hand the Global supply chains connect businesses all over the world (Boeva, 2015). The supply chains usually are related to the activities of the business and the public entities in respect to their production and economic activities. Supply chain can be described as an assembly of organizations and processes whose main aim is to develop products or services and to provide them to the end users (Dimitrov and Tolev, 2010). The supply chain leads to the transformation of the production materials and streams and encompasses the whole range of processes and activities related to manufacturing and supply.

"Greening" the supply chains

Management of the supply chains is becoming more and more popular. The supply chain is a dynamic process that involves continuous flow of materials, funds and information in several functional areas within and between participants in the chain (Jain et al., 2009). Given the fact that the supply chain covers the entire product life cycle from the processing of raw materials to delivery of finished products to the end user the focus on supply chains is a step towards the wider acceptance and development of sustainability (Ashby et al., 2012).

By focusing attention towards the environmental protection, the behavior of the deliverers in respect to the environment becomes more and more important. The suppliers are expected to cover specific criteria defined by their partners and employers for environmental protection. This leads to the establishment of environmentally friendly deliveries and products. Thus, the supply chain is 'getting greener.'

\section{Sustainable supply chains}

Sustainable management of processes is defined as a set of skills and levers that allow the company to structure its business processes in such a way as to achieve sustainable results (Gimenez et al., 2012). A sustainable supply chain is defined as an integral part of the traditional supply chain, integrating economic, social and environmental performance. In this supply chain the social indicators (i.e. nonenvironmental) refer to the stakeholders along the supply chain, including customers, shareholders and employees, etc...; economic performance is related to the financial profitability of the chain; and environmental indicators are associated to those activities that are not directly related to the production of a good, but result more from the policy imposed by the countries where different actors in the chain are located and function (Ji et al, 2014).

The sustainable development topic in the context of the supply chain management is discussed in the literature using a number of terms. The two concepts that most clearly connect sustainability and supply chain management are green supply chains and sustainable supply chain management.

An idea about the supply's sustainable management concerns the plans and activities of the company that integrate environmental and social issues in the supply chain in order to improve the environmental and social behaviour of not only the company itself but also its suppliers and customers, without compromising economic efficiency (Gimenez et al., 2012). This definition implies that companies adopt programs to improve the environmental and social consequences of their internal processes (eg. manufacturing processes in their plants) as well as initiatives to improve the impact of their suppliers and customers' activities.

Another definition of supply chains' sustainable management is given by Ahi and Searcy (2013). Based on a thorough review of the theoretical literature in the field of supply chains and sustainable development, they develop the following definition of supply chains' sustainable management:

"The creation of coordinated supply chains through the voluntary integration of economic, environmental, and social considerations with key inter-organizational business systems designed to efficiently and effectively manage the material, information, and capital flows associated with the procurement, production, and distribution of products or services in order to meet stakeholder requirements and improve the profitability, competitiveness, and resilience of the organization over the short- and long-term" (Ahi and Searcy, 2013). 
On the other hand, green management of supply chains occurs as an organizational philosophy that helps companies and their partners to achieve profit and market share by reducing the risk and impact on the environment while improving environmental efficiency (Rao and Holt, 2005). The increased pressure from the public and consumers have led to the imposition of strict environmental regulations such as the EU Directive on waste electrical and electronic equipment. These regulations force the manufacturers to incorporate the environmental considerations into their management practices (Azevedo et al., 2011). In addition, the participants in the global supply chains of any company can be held responsible for the environmental and social performance of its suppliers.

Management of the green supply chain is defined as "the integration of environmental concerns in the management of the supply chain, including product design, choice of materials, production process, delivery of the final product to the customer and product management after the end of its life" (Boeva et al., 2012). A study on the methods for the relationship between environment and trade even concludes that the supply chain is "embedded" in nature as all human actions depend on the resources that nature provides such as the necessary raw materials and the energy for the production processes (Faße et al., 2009).

\section{Sustainable supply chains in terms of strengthened regulations to protect the environment}

Deepening the problems with the natural resources protection, forces the legislators in the different countries to continuously develop and implement a range of policies for environmental protection, covering the various stages of production, distribution, use and disposal of the produced products. The greatest attention by regulatory authorities is paid to the environmental components related to climate change mitigation and the increasingly worsening quality of the soil. In this sense, new regulations and policies have been developed that are related to more than one sector of the environment (eg. concerning soil and atmosphere), and which the companies should comply with simultaneously. In this way "double" regulations for environmental protection appear (Ji et al., 2014). For instance the EU Directive on Waste Electrical and Electronic Equipment (WEEE) requires discarded electronic products to be suitable for recycling, while the Directive on end-of-life vehicles (ELVs) adopted by the EU in 2006 requiring vehicle manufacturers to ensure that $85 \%$ of the raw materials used in the cars production will be recycled. Both can be considered as regulations concerning soil protection, as discarding obsolete electrical and electronic equipment to the landfill might result in leakage of dangerous (harmful) substances in the soil. These regulations and a number of similar ones are based on the "producer responsibility" concept, prompting producers to internalize external factors in their production and turn the open chain of direct production and distribution into a closed system that encourages all participants in the chain to recycle, recover and improve product design (Ji et al, 2014). Another practice - the one of the United States, applies the concept of product liability (product stewardship). This concept is similar to the European "producer responsibility", whose importance grows mostly on the development of waste management strategies. China in 2009 also adopted a regulation for the administration of the recovery and disposal of waste electrical and electronic equipment, which is also based on the re-buy and processing of products. All these regulations in different countries are focused on the effect of solid waste disposal on the environment and aim to force manufacturers throughout the supply chain to actively take measures to reduce their environmental impact in such a way as to achieve improvements in both their economic and environmental performance. On the other hand, during various conferences and summits on climate change it was agreed that carbon emissions are the major source leading to global warming. Thus, more and more countries and governments adopt measures aimed at protecting the atmosphere by imposing a policy to reduce emissions by introducing a carbon tax or creating different market mechanisms such as emissions trading.

All these activities result in a kind of double regulations that aim to achieve the same result environmental protection - by affecting separate elements and the companies are forced to take action (voluntary or under specific regulation) to reduce their environmental impacts within the scope of all these elements. It should be noted that the influence of companies on the environment is mostly a result of the different stages of the product life cycle. Moreover, there is a close relation between the phases of the product life cycle and stages in the supply chain, so that the impact on the environment should be directed to the interaction between all partners in the supply chain (Diabata and Govindanb, 2011). 


\section{Conclusion}

Sustainability is part of our life nowadays and this is an undoubted fact. The activities in this area have started back in the 70s but in the last decade they have become inseparable from the economic life of every society. Business operations do not make an exception from this trend. Within the academic project "Corporate governance and the global supply chains" we have tried to find out how this trend influences one of the major parts of the contemporary international business namely global supply chains. It turned out that these chains have been modified by sustainable development as well. The requirements of the suppliers along the global supply chains have significantly changed and they are expected to work in an environmentally friendly manner thus "greening" the supply chains themselves. Also, a new type of supply chain occurs namely the sustainable supply chain, which integrates economic, social and environmental performance. These are only a small part of the project's findings but they are quite demonstrative for the influence sustainability has on international business activities.

\section{References}

Ahi P., Searcy C. (2013). A comparative literature analysis of definitions for green and sustainable supply chain management. Journal of Cleaner Production 52

Ashby, A., Leat, M., Hudson-Smith, M. (2012). Making connections: a review of supply chain management and sustainability literature. Supply Chain Management: An International Journal 17 (5).

Azevedo S., Carvalho H., Cruz Machado V. (2011). The influence of green practices on supply chain performance: A case study approach. Transportation Research Part E 47

Boeva B. (2015). Corporate Governance and Global Supply Chains: How Self -regulation Replaces the Lack of Regulatory Initiatives or Do Regulatory Initiatives Add Value to Corporate Governance. Economic Alternatives, Issue 4

Boeva B., Stoychev I., Zhivkova S. (2012). Mezhdinen doklad po proekt „Globalnite predizvikatelstva v opazvaneto na okolnata sreda i promenite v mezhdunarodniya biznes" [Interim Report on project "Global challenges in the environment and changes in international business"]

Brundtland G. (1987). Our Future. World Commission on Environment and Development

Diabata A., Govindanb K. (2011). An analysis of the drivers affecting the implementation of green supply chain management. Resources, Conservation and Recycling 55

Dimitrov P., Tolev M. (2010). Logistichni sistemi [Logistics Systems]

Faße A., Grote U., Winter E. (2009). Value Chain Analysis Methodologies in the Context of Environment and Trade Research. Discussion Paper No. 429, Gottfried Leibniz University of Hannover, Institute for Environmental Economics and World Trade

Gimenez C., Sierra V., Rodon J. (2012). Sustainable operations: Their impact on the triple bottom line. Production Economics 140

Jain, V., Wadhwa, S., Deshmukh, S.G. (2009). Select supplier-related issues in modeling a dynamic supply chain: potential, challenges and direction for future research. International Journal of Production Research 47 (11)

Ji G., Gunasekaran A., Yang G. (2014). Constructing sustainable supply chain under double environmental medium regulation. Int. J. Production Economics 147

Kotler Ph. (1997). Marketing Management: Analysis, Planning, Implementation, and Control. Prentice Hall

Rao, P., Holt, D. (2005). Do green supply chains lead to competitiveness and economic performance?. International Journal of Operations and Production Management 25 (9) 